\title{
Professionalisms at war? Interpreting in conflict and post-conflict situations
}

Article

Accepted Version

Tesseur, W. and Footitt, H. (2019) Professionalisms at war? Interpreting in conflict and post-conflict situations. Journal of War \& Culture Studies, 12 (3). pp. 268-284. ISSN 1752-6272 doi: https://doi.org/10.1080/17526272.2019.1644415 Available at https://centaur.reading.ac.uk/85317/

It is advisable to refer to the publisher's version if you intend to cite from the work. See Guidance on citing.

To link to this article DOI: http://dx.doi.org/10.1080/17526272.2019.1644415

Publisher: Taylor \& Francis

All outputs in CentAUR are protected by Intellectual Property Rights law, including copyright law. Copyright and IPR is retained by the creators or other copyright holders. Terms and conditions for use of this material are defined in the End User Agreement.

\section{www.reading.ac.uk/centaur}

\section{CentAUR}

Central Archive at the University of Reading

Reading's research outputs online 
This is an Accepted Manuscript of an article published by Taylor \& Francis in the Journal of War \& Culture Studies on 23 July 2019, available online:

http://www.tandfonline.com/10.1080/17526272.2019.1644415

\title{
Professionalisms at War? Interpreting in Conflict and Post-Conflict Situations
}

Wine Tesseur ${ }^{1}$ and Hilary Footitt ${ }^{2}$

${ }^{1}$ University of Reading and Ghent University, ORCID iD: 0000-0003-4882-3623

${ }^{2}$ University of Reading

\begin{abstract}
This article examines the ways in which the situational and institutional contexts of interpreting in war and in post-conflict development bring interpreting into close proximity with alternative and dominant forms of professionalism which serve to condition the work and status of the interpreters involved. By drawing on evidence from conflict situations, the professional interpreting association AIIC, and research interviews, the article calls into question traditional notions of what exactly constitutes the 'profession' of interpreting. It argues that in the context of war, military professionalism has tended to allow little space for key tenets of professional interpreting, but that recent conflicts have led to an interrogation of how such competing professionalisms might begin to coexist. In post-conflict development, the traditional models of 'development professionals' have largely concealed the role of language mediation. While the shock of war has challenged the military and interpreting professions to reassess aspects of their traditional beliefs, in post-conflict development the relative invisibility of language mediation has meant that this questioning has yet to take place.
\end{abstract}

Keywords: interpreting; languages at war; multilingualism; professionalism; development; NGOs; transnational

\section{Funding}

This work was supported by the Arts and Humanities Research Council [grant number AH/M006808/1, project name: 'The Listening Zones of NGOs']. 
This is an Accepted Manuscript of an article published by Taylor \& Francis in the Journal of War \& Culture Studies on 23 July 2019, available online:

http://www.tandfonline.com/10.1080/17526272.2019.1644415

\section{Introduction}

In contexts of conflict and post-conflict development, actors from varying cultures who speak different languages inevitably meet. In such spaces, language intermediaries are of great importance in achieving successful communication and operational effectiveness, yet their role and status are often not incorporated as key elements of analysis in research in either War and Culture Studies or Development Studies (Footitt, 2016). In Translation and Interpreting Studies (TIS), scholars have increasingly drawn attention to the complex and multifaceted role of language mediators in war and conflict (Baker, 2006; Guo, 2016; Inghilleri, 2010; Inghilleri \& Harding, 2010; Rosendo \& Persaud, 2016; Salama-Carr, 2007), within a context in which language itself was weaponized for war (Rafael, 2012). Much less, however, is known about the role of language mediators in post-conflict situations, who work in contexts that are equally transnational and multilingual. Recent work in TIS has started to address the missing link between translation and development (Marais 2014), yet systematic analyses of the role of language mediators in development are still limited to a handful of studies (Footitt, 2017; Tesseur, 2018).

This article aims to bring together evidence of the role of language mediators in conflict and post-conflict contexts to increase our understanding of what constitutes the 'profession' of interpreting. The article examines the ways in which the situational and institutional contexts of interpreting in war on the one hand, and in post-conflict development on the other, bring interpreting into close proximity with alternative and dominant forms of professionalism: the military in the case of war, and the development professional in the case of post-conflict projects. In both cases, these professions serve to condition the work and status of the interpreters involved, and more broadly, call into question traditional notions of what exactly constitutes the 'profession' of interpreting. 
We draw on data largely stemming from two research projects that investigated the role of languages in conflict and post-conflict situations. Firstly, our account on interpreters and military professionalism draws on research conducted as part of the Languages at War ${ }^{l}$ project and ensuing publications (Footitt \& Kelly, 2012b, 2012a; Kelly \& Baker, 2013; Kelly, Footitt \& Salama-Carr, 2019), which provided evidence from recent conflicts in the Balkans, Iraq and Afghanistan. Furthermore, we draw on Joint Doctrine Notes on Linguistic Support to Operations, and reactions of the professional conference interpreter association AIIC. Secondly, our account on interpreters and development professionalism draws on data collected as part of the Listening Zones of $\mathrm{NGOs}^{2}$ project, which investigated the role of languages and cultural knowledge in the work of international British development NGOs. On the basis of these data, we aim to demonstrate that in contexts of war and conflict, military professionalism has tended to produce a compelling negative framework for language intermediaries, allowing little space for key tenets of professional interpreting, but that the results of recent conflicts have led to an interrogation of the ways in which these alternative professionalisms might co-exist. In post-conflict development on the other hand, the role of language mediation has largely been overlooked in institutional frameworks, and subsumed without questioning into an accepted model of development professionalism.

We aim to make two key contributions. Firstly, in War and Culture Studies, we aim to provide further evidence of the situated nature of the role of languages and language intermediaries by comparing contexts of conflict and post-conflict, and specifically by considering how alternative professionalisms in these contexts condition the role of interpreters. Secondly, in Translation and Interpreting Studies (TIS), we aim to highlight the centrality of informal, ad-hoc translation and interpreting practices in post-conflict 
This is an Accepted Manuscript of an article published by Taylor \& Francis in the Journal of War \& Culture Studies on 23 July 2019, available online:

http://www.tandfonline.com/10.1080/17526272.2019.1644415

development, which are usually undertaken by multilingual staff who are not trained in language mediation. Competing professionalisms, the article argues, serve in both conflict and post-conflict situations to deny subjectivity and status to those engaged in the important activities of language mediation. Finally, by providing data on translation and interpreting in developing contexts, the article aims to contribute to current efforts in TIS to counter these disciplines' predominant focus on Western contexts and understandings of translation and interpreting (Marais, 2014; Tymoczko, 2009; Van Doorslaer \& Flynn, 2013).

\section{Interpreters and Military Professionalism}

Conflicts in the late twentieth/early twenty-first centuries brought interpreting into close proximity with a military definition of professionalism which would have major consequences both for traditional representations of the neutrality of the interpreter (SalamaCarr 2007: 1) and for individual interpreters themselves caught up in the violence of war. This clash of professionalisms was precipitated by major changes in Western military doctrine provoked by the events of $9 / 11$ and their aftermath. From the 1980 s to the late $20^{\text {th }}$ century, Western military understandings of war had emphasised the growing role of technology and had imagined future conflicts as battles which would be fought from an optical distance. By the late 1990s, however, with peace-keeping in the Balkans, and particularly with developments post $9 / 11$, it was clear that troops would now have to be entering the countries concerned on foot, occupying territory, and staying on there, in Iraq and Afghanistan, for example, for considerable periods. The role of technology became less relevant, while cultural awareness and an informed understanding of the local foreign culture became key tools of effective military intervention (Footitt, 2016: 211). 
This is an Accepted Manuscript of an article published by Taylor \& Francis in the Journal of War \& Culture Studies on 23 July 2019, available online:

http://www.tandfonline.com/10.1080/17526272.2019.1644415

Language, to some extent, also became part of logistics and the kit of war, as Western militaries recognised that there would necessarily be on the ground encounters which would require oral communication and language understanding. The UK Military's view of this linguistic communication was that language, just as much as culture, was a weapon to combat counter-insurgency:

UK military doctrine increasingly recognizes the importance of influence in achieving campaign objectives, reaching out to the hearts and minds of all those involved. This requires an understanding of culture and an ability to communicate our messages in a way that third parties understand, predominantly through language. Therefore, language cannot be neutral to those engaged with a crisis; if we choose to think otherwise, adversaries will exploit that choice and undermine our chances of success. (Lewis, 2012: 67)

NATO countries had for some time developed what the British called 'military linguists' with proficiency levels agreed across NATO countries and codified in Standardization agreements (STANAGs), cross-referenced against the Common European Framework of Reference for Languages (CEFR). These covered the four language skills, but made no explicit reference to translation or interpreting, although interestingly enough, the British Army continued to use terms inherited from the UK Civil Service, alongside the STANAG levels, to describe language competence, with the stages 'interpreter', above 'colloquial speaker', and 'linguist' (Kelly \& Baker, 2013: 32). For the army, however, language competences were not to be wholly a matter of language. They would be embedded in a notion of professionalism which gave the main priority to military rather than linguistic skills - languages were an 'add-on' to more important military competences, and it was recognised that if a soldier gained linguistic 
This is an Accepted Manuscript of an article published by Taylor \& Francis in the Journal of War \& Culture Studies on 23 July 2019, available online:

http://www.tandfonline.com/10.1080/17526272.2019.1644415

skills, this might actually inhibit his/her future career progression in the army (Footitt \& Kelly, 2012b).

This sense that military competences and military objectives must always define professional linguistic conduct in the field served as a compelling negative framework for what the forces called 'civilian' linguists - locally recruited non-military personnel whom they were increasingly forced to employ in order to supplement the scarce numbers and sometimes inadequate linguistic levels of their own military linguists (Kelly \& Baker, 2013: 70). These civilian linguists were, by definition, professionally deficient in that they lacked the desired military professionalism, encapsulated in the term 'security clearance', that is to say unquestioned and proven loyalty to their employer (the army), and insulation from the personal, social and emotional implications of the field of conflict (Kujamäki \& Footitt, 2019: 122). Advice given to American officers employing local interpreters in Iraq for instance warned them to be mindful of the extent to which the civilian's personal views, ethnicity or gender could impact negatively on the success of the mission: 'Your translator might have an agenda, or his dialect or tribal affiliation might not be well received.... check in advance if female translator is OK' (TRADOC, 2006).

Interpreters working with the army were thus confronted with a negative deficiency model, which we here understand as the idea that military professionalism was always the baseline against which professional behaviour and skills were being measured. The consequences of this model were to be considerable, both for the civilian linguists themselves, and ultimately for the military who employed them. At the outset of a deployment, the model allowed no space for the concept of what one might call alternative professionalisms, most notably of course that of interpreting. At first, in the hurried and chaotic first weeks of deployment, the 
This is an Accepted Manuscript of an article published by Taylor \& Francis in the Journal of War \& Culture Studies on 23 July 2019, available online:

http://www.tandfonline.com/10.1080/17526272.2019.1644415

pattern was generally ad hoc, with the army hiring civilians speedily on the spot. In this process, interpreters were defined as educated people who spoke English reasonably well. In Bosnia-Herzegovina, for example, those recruited by UNPROFOR (United Nations Protection Force) were students, sometimes high school students, teachers, engineers, who had generally received no training as interpreters. Bosnian interpreters interviewed as part of the Languages at War project for example related:

Some of them were studying English. The others didn't.... The others were kids like me. Like common kids, youngsters who were able to learn English in high school and pick it up to the level sufficient to get a job...

None of us at the time was a professional interpreter. Very few people actually had a degree in English Language. No Never. We kind of learned along the way. (Footitt \& Kelly, 2012: 188, 184)

The longer the Military stayed in an area, and the greater the linguistic demands made upon it, the more likely it became that these civilian language resources would be in some sense outsourced. One US battalion in Bosnia-Herzegovina for example outsourced its interpreting via a civilian contractor who employed heritage language speakers (speakers of the foreign language who were US citizens). This introduced an intermediate tier between military linguists and civilian linguists, Category I: 'since these people were American citizens, they had a security clearance, and they translated more classified information, and at meetings that were not, so to speak, available to local interpreters and local population' (Kelly \& Baker, 2013: 92). A professional hierarchy of interpreting was thus created in the field, with a scale of professionalism related to levels of security clearance rather than linguistic ability military linguist, outsourced interpreter, and at the very bottom, the local civilian interpreter. 
This is an Accepted Manuscript of an article published by Taylor \& Francis in the Journal of War \& Culture Studies on 23 July 2019, available online:

http://www.tandfonline.com/10.1080/17526272.2019.1644415

In these recent conflicts in Bosnia-Herzegovina, Iraq and Afghanistan, the relationship between civilian interpreters and military, set within these parameters, was marked by a tendency on the part of the military to deny subjectivity to the interpreters, since accepting such subjectivity could entail admitting the very qualities which officers had been warned against - personal agendas, ethnicities, gender considerations. Yet the failure to recognise and account for the fact that civilian interpreters were personally embedded in the fabric of their society's war would prove a particularly life-threatening and toxic omission when troops left the countries concerned. At this point, the invisible left-behind interpreter emerged into the light of media scrutiny to the very considerable discomfort of the military themselves. In the UK, for example, persistent and well-publicized press campaigns, particularly by the Times defence correspondent, Deborah Haynes, confronted the UK Army with their failure of duty of care to employees which the logistics-based approach to language and interpreting had caused. Haynes' campaign calling on the UK Government to accept its responsibilities for interpreters employed in Iraq and Afghanistan, and offer them asylum or compensation was so effective in forcing the subject onto the political agenda and providing some support for local interpreters that the British press awarded her their 'Rat up a Drainpipe award' for investigative journalism that had produced an important change in policy (Luft, 2008).

The lesson from the UK Military's experience of the interpreter in war was that its negative deficiency model of interpreting derived from the prioritisation of military skills would have to be somewhat nuanced in order to accept the existence of an alternative and linguistic professionalism. Thus, the UK MOD subsequently produced in 2013 its first ever Joint Doctrine Note on Linguistic Support to Operations notable both for its recognition of the subjectivity of civilian linguists, and for a version, although somewhat attenuated, of an employer's duty of care. The note observed that whilst guides had been published about 
This is an Accepted Manuscript of an article published by Taylor \& Francis in the Journal of War \& Culture Studies on 23 July 2019, available online:

http://www.tandfonline.com/10.1080/17526272.2019.1644415

rights and responsibilities on both sides, the needs of military logistics were still the dominating factor:

Such guidance is a benchmark and represents reasonable employment aspirations, especially concerning duty of care (both psychological and physical) and professional development. They do not represent a binding legal position and the offered terms and conditions of service may not be able to fully match the benchmark.

Whilst there was now certainly an awareness of an alternative professionalism, that of professional interpreting, and an implicit acknowledgement that local civilian interpreters were humans necessarily embedded in their local communities, the tension between operationalising the neutrality paradigms of professional interpreting, and fighting a war still remained, but at least now such a tension was explicitly recognised:

Both sides will need to agree the extent to which a civilian linguist applies nonintervention, impartiality and confidentiality guidelines if the safety of British personnel is at risk. (MOD, 2013: paragraphs 309, 310, 313)

Thus, for the UK Military, by the beginning of the twenty-first century, there was an awareness of their need for interpreters in so-called cultural insurgency operations, and the issue of alternative forms of professionalism was now being raised, but the relationship between military and interpreter professionalisms was left by the military in a still unresolved and uneasy limbo.

For the profession of interpreting itself, the violence of contemporary war would pose one of the severest challenges which this post Second World War profession had ever faced, going 
This is an Accepted Manuscript of an article published by Taylor \& Francis in the Journal of War \& Culture Studies on 23 July 2019, available online:

http://www.tandfonline.com/10.1080/17526272.2019.1644415

to the very root of its established beliefs. The notion of what constitutes professional interpreting, as Mona Baker has argued (1997), is almost entirely derived from one particular Western model which has succeeded in developing and colonising the profession - that of simultaneous interpreting - a model which had its public baptism in the trial of Nazi war criminals in 1945 (Baigorri-Jalón, 2000). Although interpreting in other forms, mostly liaison, assuredly existed before that date, what Cronin calls our 'geopolitical partiality' (2002: 387) has historically given value to this particular Western paradigm of conference interpreting, framed by the developed world's technology of booths and microphones.

From the 1940s onwards, interpreting developed into a profession: firstly, with recognised teaching programmes - the original one developed in Georgetown University in 1949 by Léon Dostert, the chief interpreter in the Nazi trial - and secondly, with the establishment of a professional association. By 1953, demand for interpreting had been growing to such an extent that a professional interpreters association was formed, the Association Internationale des Interprètes de Conférence (AIIC), and it is this Association which has largely marked out and defended the contours of the profession (Mackintosh,1999). The cornerstone of the new profession was its representation of the interpreter as an ethically neutral subject:

Members of the Association shall be bound by the strictest secrecy, which must be observed towards all persons and with regard to all information disclosed (...) Members shall refrain from deriving any personal gain whatever from confidential information they may have acquired (...) Members of the Association shall not accept any job or situation which might detract from the dignity of the profession.

(AIIC, 2012) 
This is an Accepted Manuscript of an article published by Taylor \& Francis in the Journal of War \& Culture Studies on 23 July 2019, available online:

http://www.tandfonline.com/10.1080/17526272.2019.1644415

The conflicts in Iraq and Afghanistan delivered a profound challenge to the profession of interpreting, particularly in terms of interpreter ethics and neutrality. To begin with, interpreters in these conflicts were dying. By 2009, partial figures released in the US suggested that among interpreters working with US forces, 360 had already been killed, and more than 1200 injured in Iraq between 2003 and 2008 (Fitchett, 2012: 177). Given that no official figures were kept of civilian and interpreter mortality, the real casualties were agreed to be undoubtedly higher. Whilst some professional interpreters commented that 'These people are not interpreters but taxi drivers, people who know a local language and have a smattering of English' (Kahane, 2009), others argued that a reluctance on the part of AIIC to express some sense of solidarity with these Iraqi and Afghani interpreters cast major doubt on its long-vaunted professional ethics (Kahane, 2009). An ethics solely embodied in notions of working conditions, fees, confidentiality, and loyalty to the text itself was thrown into sharp and negative relief by the actual working lives of these war interpreters - recruited without professional training, often uninformed about the nature of their missions, given uniforms by their employers, expected to have loyalty to the Military, but suspected of being potential traitors by all sides, and finally left behind to suffer vengeance attacks when the army interveners returned safely home. As AIIC interpreter Eduardo Kahane argued, ethics which concentrated solely on linguistic fidelity and impartiality failed to situate interpreters in the professional lives they were actually living, to give primacy to the subjective position of each interpreter, and to the impossibility of divorcing the personal from the professional. Interpreters in war zones might have little economic choice other than to work for the military; they might have particular personal sympathies with one side or another which could not simply be brushed aside in dangerous situations of armed conflict. Addressing this broader ethical dimension which went beyond the mechanics of professional interpreter praxis, and lives lived in formal conference interpretation booths, was both highly 
This is an Accepted Manuscript of an article published by Taylor \& Francis in the Journal of War \& Culture Studies on 23 July 2019, available online:

http://www.tandfonline.com/10.1080/17526272.2019.1644415

contentious, and extraordinarily difficult - what exactly were ethically acceptable situations (as opposed to conducts) for professional interpreters? Could praxis, good conduct, be unsituated in the actual choices and experiences of the language intermediaries who were working in Iraq and Afghanistan?

In the end, this broader and difficult debate on ethics was subsumed in an understandable and immediate desire to express solidarity. AIIC's future President argued that solidarity dictated that the association would now have to take:

An overall approach to the definition "interpreter". We recognise that a more differentiated approach could be taken: recognizing the blur between the two functions of "interpreter" and "translator" or the considerable difference in the skills of the interpreters or for whom they are working. We believe, however, that the first objective must be to save lives. (Fitchett, 2012:179)

AIIC concentrated its efforts on producing a Conflict Zone Field Guide for both civilian Translators/Interpreters and their employers which specifically recognised that these language intermediaries in war were largely untrained and unprofessional. Publicly associating professional interpreting with the fate of interpreters in war zones, AIIC emphasised interpreters' right to protection, to support, to limits on the role, to briefing, and to reasonable contractual conditions. Set beside these rights, however, was the interpreter's responsibility to be impartial, the traditional ethical neutrality of the profession of conference interpreting. The discourse of interpreter rights was still mired within unresolved discussions on interpreter ethics: 'Regardless of who engages you, serve all parties equally without 
This is an Accepted Manuscript of an article published by Taylor \& Francis in the Journal of War \& Culture Studies on 23 July 2019, available online:

http://www.tandfonline.com/10.1080/17526272.2019.1644415

expressing your opinions or sympathies. You cannot be an advocate for any cause and must declare any conflict of interest' (AIIC, 2013).

In many ways the relationship between the so-called ethically neutral position of an interpreter, and their right to safety and protection, was one which arguably concerned a wider issue - the position of an interpreter within international humanitarian law.

Examination of international legislative frameworks suggested that the legal status afforded to interpreters was in fact considerably less than that given to other categories of actors in war. Journalists for example had been specifically mentioned in Security Council Resolution 1738 of 23 December 2006, expressing concern at attacks against reporters in conflict situations (Bartolini, 2010). The difficulty in assigning a legally protected status to interpreters in war necessarily turned on the definition of 'combatant' and 'civilian'. If international law regarded 'combatant' (and therefore legitimate target of war) to be substantially equivalent to a member of the armed forces, the position of an interpreter, employed and paid by a national/international army, was arguably closer to 'combatant' than 'civilian'. Interpreter ethical neutrality in war thus had hugely important ramifications in terms of their entitlement to protection in international law.

The continued legal limbo in which interpreters in war found themselves led to the formation of a vivacious lobby group, RedT, which sought to (a) obtain for interpreters a UN Resolution, similar to Resolution 1738 protecting journalists, and (b) redefine the role of interpreters in conflict zones as being akin to that of ICRC staff, i.e. protected person status, with a RED T, rather than a RED CROSS on their shirts (RedT, 2001). With these lobbying activities, stimulated by the shock of war, the interpreting profession has found itself pushing at boundaries way beyond its traditional interests of training/maintaining contractual 
This is an Accepted Manuscript of an article published by Taylor \& Francis in the Journal of War \& Culture Studies on 23 July 2019, available online:

http://www.tandfonline.com/10.1080/17526272.2019.1644415

conditions, and a million miles away too from the profession's historic post-war locus in conference halls and international summits.

\section{Interpreters and Development Professionalism}

In contrast to the debates on interpreters involved in conflict situations, much less has been written on interpreters working in post-conflict settings. When international NGOs enter such spaces to set up development programmes and support local communities and partners, they are confronted with linguistic barriers similar to those that military forces encounter when deploying troops abroad. The context, however, greatly differs: violent conflict and immediate danger have ceased, and emphasis in development projects is placed on collaboration and participation. Despite these differences, we argue here that as in conflict situations, the dominant profession of the development worker conditions the work and status of interpreters working in post-conflict settings, and this generally results in a low profile being attributed to languages and interpreting in development settings.

The empirical work we draw on to illustrate this point comprises thirty semi-structured interviews conducted in 2016 with NGO staff members, half working within the UK, and half outside, employed by four large UK-based development NGOs. The four NGOs, including Christian Aid, Oxfam GB, Save the Children UK and Tearfund, all have a considerable history of development activity since World War II, and are currently active in over forty countries. The staff interviewed held a range of posts, including managers, advisory officers, communications specialists and translators. We here focus on what participants said about the role of translation and interpreting in their job. 
This is an Accepted Manuscript of an article published by Taylor \& Francis in the Journal of War \& Culture Studies on 23 July 2019, available online:

http://www.tandfonline.com/10.1080/17526272.2019.1644415

What emerged from the data was the low level at which multilingualism and translation are institutionalised in NGOs. All but one NGO, namely Christian Aid, had an internal translation service in UK headquarters, yet these services tended to be based on the translation of written documents, and translation mainly occurred from English into a handful of strategic languages (usually French, Spanish, Arabic, in some cases also Portuguese). These services did not respond to the need for interpreting between a wide variety of (local) languages and English or between other language pairs. Professional interpreters were occasionally hired to interpret at high-level meetings or conferences, involving diplomats, important donors or politicians, but any interpreting needs outside such official or formal contexts would usually be handled by multilingual staff. One interviewee related that NGOs did not usually hire professional interpreters because NGOs 'have got people from pretty much every language in the world somewhere in the office', although 'their key skills aren't necessarily linguistics' (INT 33, translator, UK). ${ }^{3}$

Interview data thus suggested that the general pattern in development programmes was for informal interpreting, embedded in the norms and operations of development, to largely substitute for more professionally trained interpreters. Even though NGOs were drawing on staff's language skills to make their projects a success, languages were low on the priority list during recruitment for posts in UK headquarters and in international roles. Interviewees described language skills as 'a desirable rather than an essential' (INT 11, advisory officer, UK), and as 'preferred, but in the absence of that (...) we wouldn't insist on it' (INT 24, manager, UK).

The disregard for languages as a key skill in recruitment processes implied that staff in UK headquarters and in international roles mainly worked in English, for many their native and 
This is an Accepted Manuscript of an article published by Taylor \& Francis in the Journal of War \& Culture Studies on 23 July 2019, available online:

http://www.tandfonline.com/10.1080/17526272.2019.1644415

only language. The responsibility for language mediation thus tended to be situated at oneremove from the international level. Indeed, while speaking more than one language did not tend to be part of selection criteria for UK and international roles, in-country staff were expected to speak at least two languages: their native, locally spoken language and English. This was particularly the case for higher level jobs, such as country director posts. A former UK-based NGO manager explained that:

We relied very heavily on the nationals, on our locally engaged staff who obviously were nationals of those countries and who sort of gave us our eyes and ears into the local culture and local understanding of the local scene. (INT 27, NGO manager, UK)

NGO's in-country staff tended to use their language skills daily in their work, translating forms and reports and providing oral translation between local communities, partners and international visitors. Although in-country staff had not been trained as professional interpreters or translators, NGOs gave preference to relying on their own personnel to provide language mediation rather than hiring external freelance professional translators and interpreters. This attitude was similar to that in the military, where preference was given to working with 'military linguists' who had the required military competences.

Attitudes on security and trust, however, were different between conflict and post-conflict contexts: whereas in military contexts, military linguists who had obtained security clearance and were not embedded in the local culture were given preference, development NGOs in fact preferred recruiting national staff from the local communities where a specific development project would be delivered: 'we pick staff that are from areas around there' because beneficiaries 'feel more comfortable communicating with people who are much like 
This is an Accepted Manuscript of an article published by Taylor \& Francis in the Journal of War \& Culture Studies on 23 July 2019, available online:

http://www.tandfonline.com/10.1080/17526272.2019.1644415

them' (INT 14, manager, Asia). The ideal interpreter in development programmes would thus be working for the NGO - and would therefore be familiar with its organisational values and discourse - and would be embedded in the local culture and language. These conditions could not always be fulfilled, particularly when working with local and indigenous languages. Interviewees emphasised that it was critical to consider for each community individually how it might work with the NGO, not only in terms of language 'but also acceptance and fear (...) we have to do assessments often in regards to the best way to communicate with people, because it's not a one-size-fits-all scenario' (INT 14).

These examples demonstrate that rather than considering language knowledge as a separate skill set, translation and interpreting practices in NGO work were embedded in the norms of professional development, where the new working model of international NGOs had increasingly been one of working in partnership, with efforts made to build local capacity and push power and resources to international NGOs' country affiliates and local partners (CAFOD, 2015; Poole, 2013). In such a working model, issues of trust and transparency have been described in the literature as critical precursors to sustainable, long-term relationships between development partners (Eyben, 2006: 13).

In our interviews, the link between speaking the same language and trust emerged as an important theme. Language mediators, who would speak the same language as local communities and often share the same cultural background, surfaced as playing a key role in establishing trust between the different actors in development projects, whether these interpreters belonged to the NGO, the partner organisation, or the local community. Yet despite the critical role they played in establishing trust and ensuring effective communication, interpreters received very little institutional recognition or support for their 
This is an Accepted Manuscript of an article published by Taylor \& Francis in the Journal of War \& Culture Studies on 23 July 2019, available online:

http://www.tandfonline.com/10.1080/17526272.2019.1644415

language work. As in the military, languages were seen as an add-on to the default skill set of the professional development worker. Local staff who frequently acted as interpreters and who also regularly translated or wrote material in(to) English, did not usually receive any support to further develop their language skills:

We are on our own, to be frank (...) we fear that we are forgotten, that there are non-English speaking countries. We struggle more to give the required quality to our report compared to those who are from English-speaking countries. (INT 2, manager, Africa)

Moreover, staff's linguistic skills and task set were not usually reflected in their salaries or recognised as a key part of their job role (cf. Duchêne, 2011).

In some cases, staff were given no or little advance warning that they might need to draw on their language skills. One multilingual international staff member who went to deliver a training course in Rwanda shared the fact that:

They didn't tell me until the end of day one that they needed bilingual translation. So, after a whole day speaking in English (...) they were like 'So, can you summarise the whole day in French please to the colleagues who are not fluent in English?' And I was like 'What? What are you saying?' And then on day two, actually, I had to go back in the evening and translate all the materials to French as well to have the bilingual materials, the PowerPoints and everything we'd been using and translate myself the whole day, and it was exhausting. (INT 19)

The English language skills of in-country staff were called on to translate all kinds of information, often requiring a capacity to translate what was taking place within communities 
This is an Accepted Manuscript of an article published by Taylor \& Francis in the Journal of War \& Culture Studies on 23 July 2019, available online:

http://www.tandfonline.com/10.1080/17526272.2019.1644415

in local languages into a written language that would conform to international donor requirements. A country director explained that this meant 'we're looking for individuals who have multiple skills, and in that process, there is probably a threshold capability in English language, both verbal and written' (INT 13, manager, Africa).

Interviewees emphasised that the English that was required was not just every-day, colloquial English, but rather a highly technical language consisting of an abundance of development buzzwords that are widely used in international development discourse (Cornwall \& Eade, 2010). 'Development speak' was seen as further obfuscating language mediation, because concepts that existed in English often did not exist in local languages, or the other way around. Professional interpreters and translators were described as often lacking the necessary knowledge of development discourse to be able to deliver high quality translation: 'it's difficult to find people who can understand (...) the terminology that sometimes you need to use' (INT 5, advisory officer, Latin America). In other words, professional translators or interpreters were considered as in a way professionally deficient, because they lacked the desired knowledge of the professional development worker. Another interviewee related that s/he had hired a local interpreter, but during a meeting with the local community and the partner organisation:

It came to a point that one of my partners present told me that what he [the interpreter] said is not what I have said (...) He had to stop the translator from translating and he himself, he undertook this role. For the translator from the community (...) it was a young person from the university, but he didn't understand the development jargon. (INT 2, manager, Africa) 
This is an Accepted Manuscript of an article published by Taylor \& Francis in the Journal of War \& Culture Studies on 23 July 2019, available online:

http://www.tandfonline.com/10.1080/17526272.2019.1644415

Working with an interpreter was described by several NGO workers as complex, yet staff noted that they did not usually receive guidance on how to ensure successful language mediation. Interviewees recognised that the power dynamics at play were extremely complex, and not only concerned those between NGOs and beneficiaries. Power relationships between the interpreter and local community members were also often unequal, with interpreters occupying 'a different kind of socioeconomic position compared to a poor farmer beneficiary' (INT 32, communication staff, UK). Gender differences could also play a role: 'If that translator is a man and the interviewee is a woman, the man can put in [exercise] his power saying "well that didn’t happen"” (INT 32). Interpreters were thus recognised as holding powerful positions and as acting as linguistic gatekeepers (cf. Lewis and Mosse, 2006), and development workers felt unsure how to deal with these challenges. Although NGO workers generally recognised the huge value interpreters contributed by translating and explaining cultural norms, some interviewees said that they sometimes approached interpreters with a sense of distrust: would they actually translate what people had said, or would they 'put in their own biases' (INT 32)? To avoid only hearing interpreters' own interpretations rather than 'the authentic voices' (INT 32), some would brief the interpreter, saying: 'we need word for word. We don't want the interpreter to interpret what they think the person said' (INT 32); or: 'your job is to tell me what they are saying word for word so that I get a picture' (INT 3, manager, Asia).

Some international NGOs did have guidelines for using interpreters, but staff were not always aware of their existence. For example, one staff member in this particular NGO said guidelines did not exist, because there is 'an expectation that that understanding is kind of, in the hands and in the minds and in the ways of working of people at the country and lower levels' (INT 13, manager, Africa). At the time of interviewing, there was no institutional 
This is an Accepted Manuscript of an article published by Taylor \& Francis in the Journal of War \& Culture Studies on 23 July 2019, available online:

http://www.tandfonline.com/10.1080/17526272.2019.1644415

framework or clear policy on the existence and sharing of this type of resources. However, individual as well as cross-organisational initiatives had started to emerge. For example, in 2015, a set of guidelines on 'Using local field staff as interpreters' (Wright, 2015) in the context of NGOs' journalistic work was produced by an academic at the request of the Disasters Emergency Committee, an organisation that brings together 13 leading UK aid charities, among which are all four NGOs included in our interview data. However, these guidelines were predominantly intended for press officers, and this might be one of the reasons why only one NGO staff member referred to them during interviewing.

In sum, although individual aid workers often recognised the complexity of working with interpreters and of acting as a language mediator, little institutional recognition was given by international NGOs to interpreting as a profession for which training and guidance were needed. This can be interpreted as a consequence of current working models: donors have become more insistent on concrete evidence to demonstrate NGOs' accountability (e.g. DFID's 2014 working strategy of 'payment by results'). In an institutional culture of monitoring and evaluation where priority has been given to quantitative measures and reporting according to donors' requirements (Eyben et al. 2015), the need for qualitative relational issues is often overlooked. In the words of one NGO worker: 'I think a consequence of that [donors' insistence on evidence], I don't think it's a desire, but a consequence of that is that attention to some of the softer skills, some of the capabilities that exist in a more vocal or a more oral tradition are being downplayed or forced out' (INT 13). Thus, despite NGOs' discourse on the importance of working in equitable partnerships and with local organisations and communities, language and translation have been marked as being of secondary importance. 
This is an Accepted Manuscript of an article published by Taylor \& Francis in the Journal of War \& Culture Studies on 23 July 2019, available online:

http://www.tandfonline.com/10.1080/17526272.2019.1644415

\section{Concluding Remarks}

In this article we have illustrated the importance of analysing the role of language mediators in conflict and post-conflict situations. Our analysis shows, amongst other things, that in the case of the military, preference has been given to interpreters who are not embedded in the fabric of local society, but that the opposite was true for interpreters in post-conflict situations. Our data indicate the importance of issues of trust and security clearance in relation to language mediators, and how these differ between the two contexts under investigation. Furthermore, in post-conflict development, interviewees emphasised the key role that language mediators play in establishing trust and ensuring effective communication between NGOs and local communities. Without their contribution, development projects would lead to failure. This example illustrates the critical role of these multilingual agents, and supports our argument that languages and language mediators should be placed at the heart of conflict and post-conflict investigations.

Furthermore, our analysis has shown that including practices of both formal and informal interpreting are crucial for an in-depth understanding of the dynamics of conflict and postconflict development. Our evidence demonstrates the fact that the current working model in development is one of informal interpreting, often provided by staff who identify themselves as development workers rather than as translators or interpreters. In both conflict and postconflict situations, interpreters at work often did not adhere to traditional (even if contested) notions of the interpreter as 'neutral' or as a trained professional. Our discussion thus illustrates the point that if we limit our investigations of conflict and post-conflict contexts to traditional understandings of interpreting, we risk excluding many of the practices that are vital to the relationships that develop on the ground in war and development contexts. These findings emphasise the need to question both the alternative professionalisms of those with 
This is an Accepted Manuscript of an article published by Taylor \& Francis in the Journal of War \& Culture Studies on 23 July 2019, available online:

http://www.tandfonline.com/10.1080/17526272.2019.1644415

whom interpreters and translators work and our established Western notions of what constitutes interpreting or translation. Our data illustrates the need to include more overt characteristics of translation and interpreting in non-Western and informal contexts into existing definitions (Marais, 2014; Tymoczko, 2006).

We have argued that the acceptance of the professionalism of interpreters depends on other professions surrounding the interpreter. In both conflict and post-conflict situations, interpreting has been considered as the lesser profession. In conflict situations, the problematics of competing professionalisms is now being raised as a serious question to address, and there is an understanding of the need for a duty of care for language professionals. In contrast, in post-conflict development, the relative invisibility of language mediation in apparently quiescent contexts has meant that this questioning of alternative professionalisms, and the recognition of the value language skills may add to development work and building relationships, has yet to take place. Creating a similar duty of care for language mediators in development would be a first and powerful step to support and celebrate the multilingual skills of development workers institutionally. 
This is an Accepted Manuscript of an article published by Taylor \& Francis in the Journal of War \& Culture Studies on 23 July 2019, available online:

http://www.tandfonline.com/10.1080/17526272.2019.1644415

\section{References}

AIIC 2012. Code of Professional Ethics [online]. Available from: http://aiic.net/page/6724/ [Accessed 21 March 2019].

AIIC 2013. Conflict Zone Field Guide [online]. Available from:

http://aiic.net/page/3853/aiic-red-t-and-fit-introduce-the-first-conflict-zone-field-guide-lang/1 [Accessed 21 March 2019].

Baigorri-Jalón, J., 2000. La interpretación de conferencias: el nacimiento de una profesión. De París a Nuremberg. Granada: Comares.

Baker, M., 1997. Non-cognitive constraints and interpreter strategies in political interviews. In: K. Simms, ed. Translating Sensitive texts: Linguistic Aspects. Amsterdam: Rodopi, 11129.

Baker, M., 2006. Translation and Conflict: a Narrative Account. London and New York: Routledge.

Bartolini, G., 2010. General Principles of International Humanitarian Law [online seminar aiic.net 9 March], Available from: http://aiic.net/page/3396 [Accessed 21 March 2019].

CAFOD, 2015. Charter for Change: Localisation of Humanitarian Aid [online]. Available from: http://charter4change.org/ [Accessed 21 March 2019].

Cornwall, A., \& Eade, D., eds. (2010). Deconstructing Development Discourse: Buzzwords 
This is an Accepted Manuscript of an article published by Taylor \& Francis in the Journal of War \& Culture Studies on 23 July 2019, available online:

http://www.tandfonline.com/10.1080/17526272.2019.1644415

and Fuzzwords. Rugby: Practical Action Publishing with Oxfam GB.

Cronin, M., 2002. The Empire talks back: orality, heteronomy and the cultural turn in interpreting studies. In F. Pochhacker and M. Shlesinger, eds. The Interpreting Studies Reader. London: Routledge, 387-397.

DFID, 2014. Sharpening incentives to perform: DFID's Strategy for Payment by Results. London: DFID.

Duchêne, A., 2011. 'Néolibéralisme, inégalités sociales et plurilinguisme: l'exploitation des ressources langagières et des locuteurs'. Langage et Société, 136 (2), 81-108.

Eyben, R., ed., 2006. Relationships for Aid. Abingdon and New York: Earthscan.

Eyben, R., et al., eds., 2015. The Politics of Evidence and Results in International Development: Playing the Game to Change the Rules? Rugby: Practical Action Publishing.

Fitchett, L., 2012. The AIIC project to help interpreters in conflict areas. In: H. Footitt and M. Kelly, eds. Languages and the Military. Alliances, Occupation and Peace Building. Basingstoke: Palgrave Macmillan, 175-185.

Footitt, H., 2016. War and Culture Studies in 2016: Putting 'Translation' into the Transnational? Journal of War \& Culture Studies, 9 (3), 209-221. 
This is an Accepted Manuscript of an article published by Taylor \& Francis in the Journal of War \& Culture Studies on 23 July 2019, available online:

http://www.tandfonline.com/10.1080/17526272.2019.1644415

Footitt, H., 2017. International Aid and Development: hearing multilingualism, learning from intercultural encounters in the history of OxfamGB. Language and Intercultural Communication, 17 (4), 518-533.

Footitt, H., and Kelly, M., eds., 2012a. Languages and the Military: Alliances, Occupation and Peace Building. Basingstoke: Palgrave Macmillan.

Footitt, H., and Kelly, M., 2012b. Languages at War. Policies and Practices of Language Contacts in Conflict. Basingstoke: Palgrave Macmillan.

Guo, T., 2016. Surviving in Violent Conflicts: Chinese Interpreters in the Second SinoJapanese War 1931-1945. London: Palgrave Macmillan.

Inghilleri, M., 2010. You don't make war without knowing why: The decision to interpret in Iraq. The Translator, 16 (2), 175-196.

Inghilleri, M., and Harding, S.-A., eds., 2010. Translation and Violent Conflict. Special Issue of The Translator, 16 (2).

Kahane, E., 2009. The AIIC resolution on interpreters in war and conflict zones [online]. Available from: http://aiic.net/page/3196/ [Accessed 21 March 2019].

Kelly, M., and Baker, C., 2013. Interpreting the Peace. Peace Operations, Conflict and Language in Bosnia-Herzegovina. Basingstoke: Palgrave Macmillan. 
This is an Accepted Manuscript of an article published by Taylor \& Francis in the Journal of War \& Culture Studies on 23 July 2019, available online:

http://www.tandfonline.com/10.1080/17526272.2019.1644415

Kelly, M., Footitt, H. and Salama-Carr, M., eds., 2019. The Palgrave Handbook of

Languages and Conflict. Cham: Palgrave Macmillan.

Kujamäki, P., and Footitt, H., 2019. Military History and Translation Studies: Shifting

Territories, Uneasy Borders. In M. Kelly, H.Footitt and M. Salama-Carr, eds. The Palgrave

Handbook of Languages and Conflict. Cham: Palgrave Macmillan, 113-136.

Lewis, D., and Mosse, D., ed., 2006. Development Brokers and Translators: The

Ethnography of Aid and Agencies. West Hartfort, CT: Kumarian Press.

Lewis, J., 2012. Languages at War: a UK Military of Defence Perspective. In: H. Footitt and

M. Kelly, eds. Languages and the Military. Alliances, Occupation and Peace Building.

Basingstoke: Palgrave Macmillan, 58-69.

Luft, O., 2008. Deborah Haynes wins investigative reporting award. The Guardian, 11 November.

Mackintosh, J., 1999. 'Interpreters are made not born'. In: I. Kurz and M. Bowen, eds. History of Interpreting. Special Issue Interpreting, 4 (1), 67-80.

Marais, K., 2014. Translation Theory and Development Studies: A Complexity Theory Approach. New York and Abingdon: Routledge.

MOD 2013. Joint Doctrine Note 1/13: Linguistic Support to Operations. Bicester: DCDA Operations Centre. 
This is an Accepted Manuscript of an article published by Taylor \& Francis in the Journal of War \& Culture Studies on 23 July 2019, available online:

http://www.tandfonline.com/10.1080/17526272.2019.1644415

Poole, L., 2013. Funding at the sharp end: Investing in national NGO response capacity. London: CAFOD.

Rafael, V. 2012. 'Translation and the US Empire. Counterinsurgency and the resistance of language'. The Translator, 18 (1): 1-22

Rosendo, L. R., and Persaud, C., eds., 2016. Interpreting in conflict situations and in conflict zones throughout history. Special Issue of Linguistica Antverpiensia, New Series, 15.

Salama-Carr, M., ed., 2007. Translating and Interpreting Conflict, Amsterdam and New York: Rodopi.

RedT, 2001. About RedT [online]. Available from: http://red-t.org/about.html [Accessed 7 February 2018].

Tesseur, W., ed., 2018. Researching translation and interpreting in Non-Governmental Organisations. Special issue of Translation Spaces, 7(1).

Tymoczko, M., 2006. Reconceptualizing Translation Theory: Integrating Non-Western Thought about Translation. In T. Hermans, ed., Translating Others, Vol 1. Manchester: St Jerome, 13-32.

Tymoczko, M., 2009. Why translators should want to internationalize translation studies. The Translator, 15 (2), 401-421. 
This is an Accepted Manuscript of an article published by Taylor \& Francis in the Journal of War \& Culture Studies on 23 July 2019, available online:

http://www.tandfonline.com/10.1080/17526272.2019.1644415

TRADOC, 2006. Arab Cultural Awareness 58 Factsheets. Handbook no.2, office of the

Deputy Chief of Staff for Intelligence US Army Training and Doctrine Command, Ft.

Leavenworth, Kansas.

Van Doorslaer, L., and Flynn, P., eds, 2013. Eurocentrism in Translation Studies.

Amsterdam: John Behnamins.

Wright, K., 2015. Using local field staff as interpreters [online]. Available from:

http://odihpn.org/resource/interpreter-guidelines/ [Accessed 21 March 2019]

\footnotetext{
${ }^{1} \mathrm{http}: / / \mathrm{www} \cdot$ reading.ac.uk/languages-at-war

2 http://www.reading.ac.uk/listening-zones-ngos

${ }^{3}$ All interviews have been anonymised and transcripts are not publicly accessible to protect interviewees' identities. For the same reason, the organisation and specific geographical location of interviewees cannot be revealed. Instead, general indications of the interviewees' role within the organisation and their broad location are shared to provide context.
} 